\section{Google Book Search settlement}

Judge Denny Chin's ruling in the Google Book Search settlement - an anticipated decision for the library community - has created more questions for the future of mass digitization projects and the fate of orphan works.

On March 22, Chin, for the U.S. District Court Southern District of New York, rejected the settlement among the parties in The Author's Guild et al. v. Google Inc.

In his opinion, he stated that, "While the digitization of books and the creation of a universal digital library would benefit many, the [Amended Settlement Agreement] ASA would simply go too far. It would permit this class action-which was brought against defendant Google Inc. to challenge its scanning of books and display of 'snippets' for on-line searching - to implement a forward-looking business arrangement that would grant Google significant rights to exploit entire books, without permission of the copyright owners. Indeed, the ASA would give Google a significant advantage over competitors, rewarding it for engaging in wholesale copying of copyrighted works without permission, while releasing claims well beyond those presented in the case."

In response, Jonathan Band, the Library Copyright Alliance's (LCA) legal consultant on copyright, updated the GBS March Madness chart created last year to depict the possible paths forward with the settlement (available at www.librarycopyrightalliance.org/bm doc /gbs-march-madness-diagram-final.pdf).

The potential options for the parties moving forward include: 1) appealing the decision, 2) negotiating a new agreement, 3) moving forward with litigation, or 4) walking away. The next step is the status conference Chin scheduled for April 25, where the parties to the settlement instruct the judge on how they will proceed with the case.

Jenni Terry is press officer at ALA's Washington Office, e-mail: jterry@alawash.org
In addition, LCA (comprised of ALA, ACRL, and the Association of Research Libraries) also enlisted Band to issue "A Guide for the Perplexed Part IV: The Rejection of the Google Books Settlement" (available at www.librarycopyrightalliance. $\mathrm{org} / \mathrm{bm} \sim \mathrm{doc} /$ lca_gbsstmt24mar11.pdf) to help inform the library community about the basis for the judge's decision and its possible impact on libraries.

At the recent ACRL 2011 conference in Philadelphia, Corey Williams, a lobbyist and associate director of the ALA's Washington office, led an informal roundtable discussion on the impact of the judge's decision (pending the parties next steps) and the potential for renewed interest in pursuing legislation on orphans works-those copyrighted works whose rights holders can not be identified or found.

Discussion among ACRL members reflected a strong interest in librarians developing their own set of best practices for digitizing and making orphan works available. In addition, concerns were expressed that relying solely on a fix from Congress with regard to orphan works may result in legislation language that would be unduly burdensome, and therefore, not useful to the library community.

Additional information about the case, including the complete "Guide to the Perplexed" series, is available at wo.ala.org/gbs/.

\section{National Library Legislative Day}

The 2011 National Library Legislative Day (NLLD) is quickly approaching. The event will be held on Monday, May 9, and Tuesday, May 10, at the Liaison Hotel in Washington, D.C.

With a Republican-led House of Representatives and a Democrat-led Senate, many leaders in Congress have different ideas about the best course of action for our na-

(continues on page 308) 
Linda Galloway has been appointed biology, chemistry, and forensic sciences librarian at Syracuse University.

Shelley Hayreh is the new archivist for Drawings and Archives at Columbia University's Avery Library.

Jim Holmes is now technology and media resources librarian at Reed College.

Andrea Jarratt has been named reference librarian at the Thomas Cooper Library at the University of South Carolina.

Jonathan Koffel has been appointed liaison/information specialist in the Health Sciences Libraries at the University of Minnesota.

Mary Miller has joined the University of Minnesota Libraries as collection management and preservation strategist.

Nick Patterson is now music librarian at Columbia University.

Roy Patterson has been appointed associate librarian at the A. Pierre Guillermin Library of Liberty University.

Rachel Radom is now instructional services librarian for undergraduate programs at the University of TennesseeKnoxville Libraries.

Kathy Snediker is now reference librarian at the Thomas Cooper Library at the University of South Carolina.

David Stern has been appointed associate dean for public services at Illinois State University.

\section{Retirements}

Christine Kubiak retired from Illinois State University library after serving 20 years as the university's music librarian.
Karmen Crowther has retired as professor and business librarian at the University of Tennessee-Knoxville Libraries and is now professor emerita.

Beth Schobernd retired as the associate dean for technical services and facilities from Illinois State University library after 22 years of service. Schobernd served as head of the library's preservation department prior to working in administration.

\section{Deaths}

Elizabeth (Betty) Meehan-Black, head of order management and assistant head of the Monographic Services Department at the University of North Carolina (UNC)-Chapel Hill Library has died. Meehan-Black joined the UNC Library staff in 1986 as head of bibliographic searching. She held a number of increasingly responsible management positions in acquisitions and technical services at the library. In recognition of her contributions to the library and the profession, Meehan-Black was named an honorable mention for the Library's Outstanding Employee of 2010 award. Meehan-Black was deeply involved in the work of many professional associations. She was a member of the executive committee of the North Carolina Library Association and the association's elected representative to the Southeastern Library Association; president of the Librarians' Association at UNC-Chapel Hill (2001-02); and a member or leader of numerous committees for those and other professional organizations. $\boldsymbol{n}$
("Washington Hotline, cont. from page 296)

tion-particularly as we continue our efforts to recover from the economic recession. Members need to hear from constituents that support for libraries is always the best thing for our nation.
ALA has reserved a block of rooms at the Liaison Hotel at a reduced rate at the hotel, but they are going quickly. The block is listed under American Library Association 2011. Call 1-866-AFFINIA to make a reservation.

For more information or to register for NLLD, go to www.ala.org/nlld. $\boldsymbol{n}$ 